\title{
水路の階層に基づく用水路ネットワークの 機能評価手法に関する研究 FUNCTIONAL EVALUATION OF IRRIGATION CANAL NETWORK BASED ON HIERACHICAL CHANNEL ORDER
}

\author{
樽屋啓之 1 藤山 宗 2 ・中田 達 3 ・浪平 篤 1 \\ Hiroyuki TARUYA, So FUJIYAMA, Toru NAKADA and Atsushi NAMIHIRA \\ 1正会員 農(博) 農研機構農村工学研究所（†305-8609 茨城県つくば市観音台2-1-6） \\ 2非会員 農(修) 株式会社三祐コンサルタンツ（テ170-0004 東京都豊島区北大塚1-13-17） \\ 3 非会員 農(博) 農研機構農村工学研究所（テ305-8609 茨城県つくば市観音台2-1-6）
}

\begin{abstract}
This study proposes a new method for evaluating canal functions based on the concept of networking and then verifies the effectiveness of that method for the purpose of smoothly promoting upgrades to future systems and linkage with river management. To begin, it arranges thinking concerning nodes and links in order to convert a farm irrigation system into a network model based on three basic canal functions, specifically the theories of 1) delivery function, 2) collector function, and 3) connector function. Next, it creates a model of an irrigation canal network based on such thinking and then proposes a method for ranking irrigation channel links by introducing a new irrigation canal order that is based on a layered structure.
\end{abstract}

Key Words : Irrigation canal network, hierarchical structure, delivery function, collector function, connector function

\section{1. 序論}

農業における灌兓・排水，すなわち農業水利の技術は， 国内の長い伝統と歴史を有している．特に，1899年に耕 地整理法（旧法）が制定され，農地の改良事業が最初に 制度化されて以降は, 近代農業士木, 現代に通じる新た な農業水利の歴史が始まった ${ }^{1)}$. その後は国内の河川管 理の発展過程と同調し, ときに競合しながらも, 密接な 結びつきを維持しながら発展してきた.

国内で進められてきた水利事業は，旧来の小さなシス テムを公共的に統合化し，水利用を許可水利権化するこ とを主流としてきたが，末端農家の水利慣行は基本的に 継承されてきた，そして国内に拡がる広大な農村地帯の 水循環を管理し，そこに一定の秩序を与えてきたのは， 長い歴史に支えられ継承されてきた農家や水利組合など による水利慣行であり，それらを束ねる上位組織として の土地改良区や自治体の階層的管理であり, その総体と しての農業水利システムの存在であったと考えられる.

階層構造を持つことは，農業水利システムの基本的特 性2)であり，特に新規の開拓地では，システムの階層が
水路規模別に整然と計画的に配置されるのを見ることが できる．一方，長い更新の歴史を経た古いシステムの階 層は一般に複雑である. 農業水利システムを次世代の資 産として継承するためには，このような特性をふまえて 機能を評価できる技術体系の整備が求められている.

また，特に東日本大震災を一つの転換点として，大き く動き始めた国土強勒化などのインフラ整備の動きが重 要である. 農業水利を支える水路は国内の隅々まで張り 巡らされており, 国土形成の視点からの評価, 将来的に は，河川インフラとの連結をも視野に入れた公共的な防 災機能強化のための技術体系作りが求められている.

そこで，本研究は，農業水利の中で人為的な管理制御 下にある用水路のレギュレーションシステムを対象とし て，階層をふまえたネットワーク構造で定式化すること により，インフラの持つネットワーク機能を評価するた めの新たな手法を提案する.

階層の違いに基づいた水路（流れ）の管理または制御 に関する先行研究として, 血管の分岐の形態と生命活動 との関係に関する分析 ${ }^{3)}$ ，城下町を対象とした水路によ る庭園への水の引き込みと景観に関する分析 ${ }^{4)}$, 都市空 間における遣り水景観を構成する水路の階層構造に関す 
る分析5などを挙げることができる、いずれの研究もシ ステムの目的に照らし, システムの持つ階層構造とその 管理の間に関係性を見出そうとする点が共通している. また, 物流（輸送システム）を対象としたグラフ理論と ネットワーク形態分析に基づく階層構造の研究けは，同 じレギュレーションシステムの特性を持つ農業水利と共 通点が多く, 水路ネットワークの定式化のために, 階層 性の考え方を中心に取り込むことが可能である.

そして，特に本研究において強調したいのは，Horton が提案し，Strahlerが改良した河川位数（stream order）の 考え方》ををヒントにした新しい水路用の位数の導入とそ の有効性の検証である. 河川位数は農業水利における排 水路の機能を説明できるが，用水路の機能を説明できず， 説明のできる新たな概念が必要ではないかということが 着想のきっかけであった. 用水路の位数概念による既往 の評価研究が無いことから, 本研究により新たなネット ワーク機能の評価手法として提案する.

\section{2. 用水路のネットワーク化と階層付け}

\section{（1）水路ネットワークのモデル化手法}

一般的に, ネットワークの構造は, 線（link）と点 （node）によって表示される，本節においては，例えば 水路の路線区間をlinkで，それらが繋ぐ水利施設や装置 などをnodeで置き換えることなどによって，用水路と排 水路を含む全ての水路をネットワーク型でモデル化する 手法を考える.

linkは水路の路線区間であると同時に，流れの方向を 持つ要素であることに注意すれば，路線区間のlinkへの 置き換えは困難ではない，一方，nodeが表すべき実体ま たは機能については，もう少し分析を要する．水路の ネットワークにおいては, 輸送の対象を水として, node が水の流れを制御する機能を持つと考えれば，情報ネッ トワークと同様な構造を組むことができるであろう.

そこで, 水路の機能に関する, アメリカ開拓局 (USBR)の整理方法8) を導入する，それによれば，水路 が持っている基本的な機能は次の3つのユニット（シス テム）で表すことができるとされる，すなわち、(1) Delivery system（分配システム, 分配機能), (2)Collector system（回収システム, 回収機能), (3)Connector system （連結システム，連結機能）の3つである.

方向を持つlink と，3つの異なる機能を持つnodeの違い が分かるように, (1)〜(3)の3つのユニット（システム) を，図-1のように表現することができる，次節以降の議 論においては，これら3つのユニットで構成される水路 による流れのレギュレーションシステム全体のことを 「水路ネットワーク」として取り扱うことにする.

\section{（2）分配 - 回収 - 連結点が持つ水理学的な意味と機能}

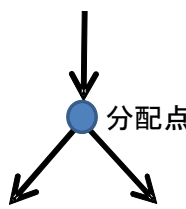

分配システム Delivery system

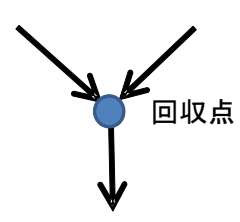

回収システム Collector system

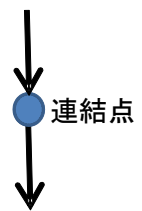

連結システム Connector system

\section{図-1＼cjkstart水路が有する基本的な機能}
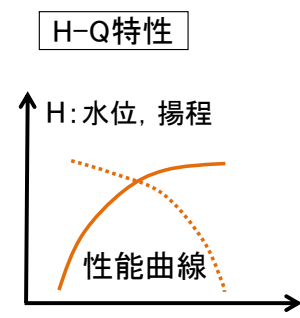

$\mathrm{Q}$ : 流量
QH-T特性

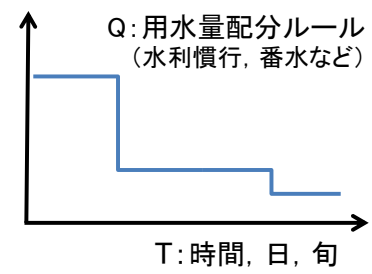

図-2 水理学的な機構 図-1における各nodeの機能の違いは，流れに対する制 御方法の違いであった. そこで, nodeに対して，さらに 水理学的な説明を補足して違いを明らかにする.

まず，分配システムは用水路に見られる典型的なシス テムに位置づけられ，流量を所定のlinkに分配する機能 を果たす。nodeの上下流のエネルギー勾配を制御して nodeから所定の流量を分配する. 具体的水利構造物とし ては, 取水工, 分水工, ポンプ, 角落としセキ板, 余水 吐き，放流工などが該当する。

次に，回収システムは排水路に見られる典型的なシス テムに位置づけられ，流量を所定のlinkから回収する機 能を果たす。 nodeの上下流のエネルギー勾配を制御し て, nodeに接続するlinkから所定の流量を回収する. 具 体的構造物としては，合流工，ポンプ，注水工，集水渠 などが該当する.

最後に, 連結システムは, nodeにおいて流量の分配と 回収のためのlinkを持たないが，nodeの上下流において， エネルギーと流量の両方，またはどちらか一方を直接制 御するためのシステムに位置づけられる. 具体的構造物 としては，水位チェックゲート（エネルギーの調整）， 落差工（エネルギーの調整）などが該当する.

\section{（3）Nodeが持つ機能とその性能項目}

3つのシステムに共通する機能は，いずれもエネル ギーまたは流量を制御することである，さらに各nodeに 対応する水利施設（上述の例で示したもの）には，施設 自体が持っている水理学的な機構（セキやポンプなど） と, それに応じた $\mathrm{H}-\mathrm{Q}$ 特性（水位または揚程と流量と の間の特性または性能曲線のこと，以下「 $\mathrm{H}-\mathrm{Q}$ 特性」 と称する）が必ず存在する（存在しない場合は制御不能 ということである）。また，流量や水位は制御変数であ 
り，これらの制御変数はnodeごとに制御目標值が決めら れていて, $\mathrm{QH}-\mathrm{T}$ 特性（流量・水位の時系列特性のこと, 以下 $「 \mathrm{QH}-\mathrm{T}$ 特性」と称する）として表示される．以上 の2種類の特性は, nodeの機能を発揮するための性能項 目として位置づけられる．特に次節以降で説明する用水 路ネットワークの持つnodeの特性は図-2のように整理さ れる. 地域に残る水利慣行などは基本的にこの性能項目 で説明可能と考えられる.

\section{（4）用水路ネットワークの持つ機能}

用水路ネットワークは，水源の用水を個別農地に分配 することを目的とするので，(1)で説明した図-1の分配 システムを中心に組み立てられる．また，路線ごとの流 量の大きさは，ゴールである農地面積（受益面積）の積 み上げで決まる。下流に向かって何度かnodeを経るたび に，linkは，幹線水路，支線水路，末端水路の順にlinkの 規模が階層的に減少する. 同時に, node とlinkを管理す る組織（国，県，土地改良区，市町村など）の階層も下 がる．階層構造を持つことは，用水路ネットワークの持 つ基本的特性の一つである.

\section{（5）受益面積に基づく用水路のランク付け}

本節では，河川位数のアナロジーにより，用水ネット ワークの階層を客観的な位数（「用水路位数」と定義す る）で表示する方法を提案する.

図-3（a）は，河川の順位付けの方法として，Horton が提案しStrahlerが改良した河川位数（Stream order）の 考え方を図示したものである，河川位数は，水源に端を 発する河道の位数を全て1とし，ある河道と同じ位数の 河道との合流で位数を 1 つげ，小さい位数の河道との 合流では位数を変化させない，というルールで設定され る指標である.

この考え方を使い，用水路ネットワークの用水路位数 を以下のように設定する．まず，河川位数の集水面積を 末端用水路の受益面積に置き換えて考え，河川位数とは 逆に末端から上流に向かって追跡する. 河川位数で水源 に端を発する河道の代わりに，用水路位数では，図-3

(b) のように，末端用水路linkの位数を 1 とする.

そして，位数 1 のlinkの上流側のnodeで同じ位数のlink が分岐する場合には，上流に向かって本線linkの位数を 1つ上げる. 本線linkよりも小さい位数のlinkが分岐する 場合には，上流に向かって本線linkの位数を変化させな い. 以上を，用水路位数の設定ルールとする.

\section{（6）エネルギ一損失に基づく用水路のランク付け}

現場では，同一のlink内に多数の小規模な分岐 （node）が連続する場合があり，(5)の方法で判断のつ かない場合には，本節の方法により用水路位数を判定す ることにする.

一般に，幹線linkの持つ全エネルギーは，ネットワー

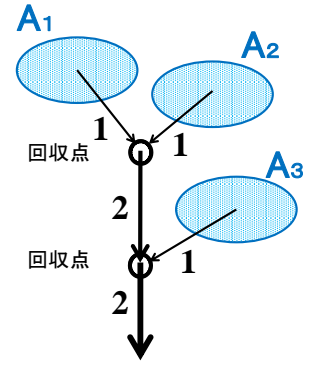

$A_{n}:$ 集水面積

(a) 河川位数

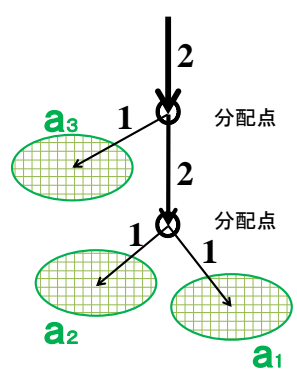

$a_{n}:$ 受益面積

(b) 用水路位数
図-3 用水路位数の概念

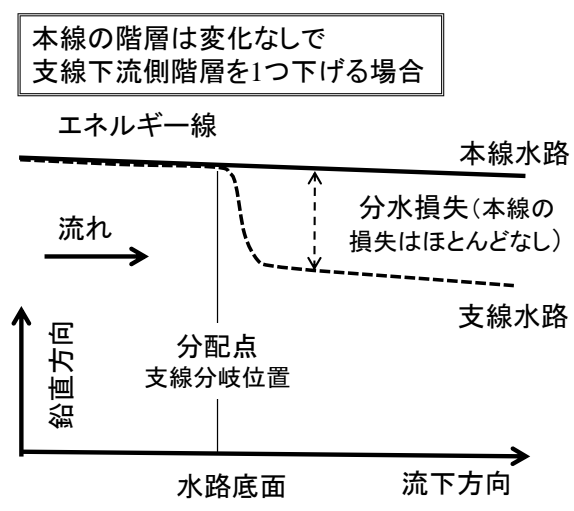

(a) その1

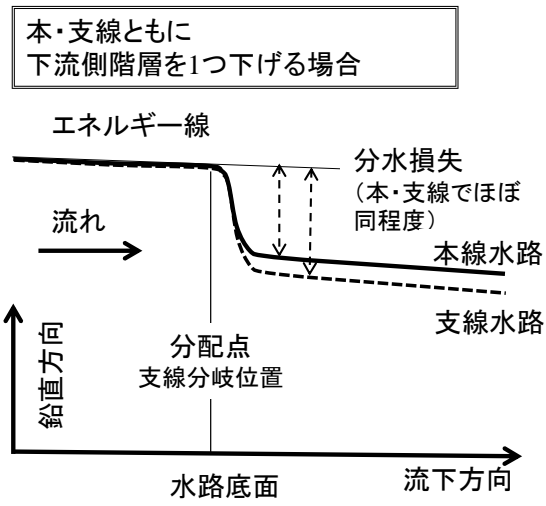

(b) その2

図-4 エネルギ一と階層

ク末端方向に減少するので，エネルギーの低下に着目し たランク付けを考える．そこで，(5)の方法とは異なり， 流れを上流側から追跡し，流れの分岐点（node）で発生 するエネルギー損失を目安とする，分岐後の 2 本（以 上）のlink（本線と支線）の比較により，図-4（a)のよう に分岐時の損失が相対的に無視できる本線linkでは位数 を変化させず，支線のみ1つ下げる，一方，図-4(b)のよ うに両link（本線と支線）が同等な損失を生じる場合は, 両者共に位数を 1 つげるルールとする。「相対的に無 視できる」などの表現に見られるような，一部の判別基 準において残る曖昧な点に関しては，今後事例調查を重 ねて解消させたい. 


\section{3. 直分問題への適用事例}

\section{（1）用水路の直分とそれに由来する問題}

水路の直分（ちょくぶん）とは，図-5の写真に示すよ うに，用水路の側壁に設けられた小口径の取水口（オリ フィス）から，用水路に隣接する水田に用水を直接引き 込む分水方法である。 一般に，オリフィスには分水ゲー トが併設され，その操作は隣接水田の農家に委㸚られて いる．直分は所定の分水位さえ確保できていれば，安定 した自由な取水を続けることが，その水理学的構造から 保証される.

現在の農家は兼業農家の割合が多いために，直分を管 理する農家による取水は出勤前の早朝に開始され，停止 は帰宅後の夕方に行われることが一般的である。その結 果，各々の農家による取水の開始および停止時刻が異な り, 各々の取水量も異なる. 土地改良区に代表される施 設管理者は，限られた用水資源を確保するため，各々の 農家による直分のゲート操作に対して節水指導を行うこ とがあるが，現実には農家主導の自助努力だけで節水を 実現することは難しい.

さらに，直分が用水路ネットワークにとって厄介な存 在となる場合がある。その典型的な問題は, 長大な幹線 用水路において多数の直分が上下流に連続的に存在する 区間において現れる，前章で述べたとおり，幹線〜支線 を経て末端に至る階層構造が，用水路ネットワークの基 本構造であるのに対し, 幹線水路に農家管理の末端水路 が直結する直分の構造は，中間階層を省略した不規則構 造である. 不規則構造の過剩取水に基づく用水不到達の 問題, 上下流の不均等分配などの問題が, 長大幹線用水 路で発生する. 以下この問題を分析する.

\section{（2）長大幹線水路の直分問題の分析}

図-6に，適切な水路統合が実施された場合の，統合前 後における用水路位数の変化を表示した. 図-6（a）は，

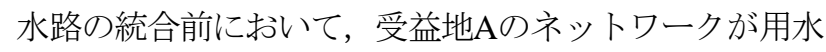
路位数 3 の水路から分水を行い, 順次, 階層を下げる構

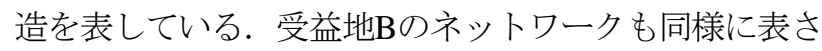
れる. 図-6 (b) は, 受益地AおよびBのネットワークに おいて，取水口の統合が行われた場合，用水路位数 3 同 士の水路が統合し，上流に，より高い用水路位数4の水 路が形成されることを表している。これらの過程では, 直分が幹線水路に現れることはない。

図一7に，不適切な水路統合が実施された場合の，統合 前後における用水路位数の変化を表示した. 図-7（a） は，水路の統合前において，受益地Aのネットワークが 用水路位数 2 の支線・末端水路から直分を行う構造を表

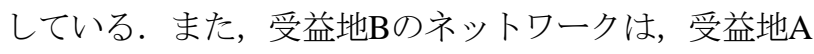
のネットワークよりも高次の用水路位数 3 の幹線・支線 水路から分水を行い, 順次, 階層を下げる構造を表して

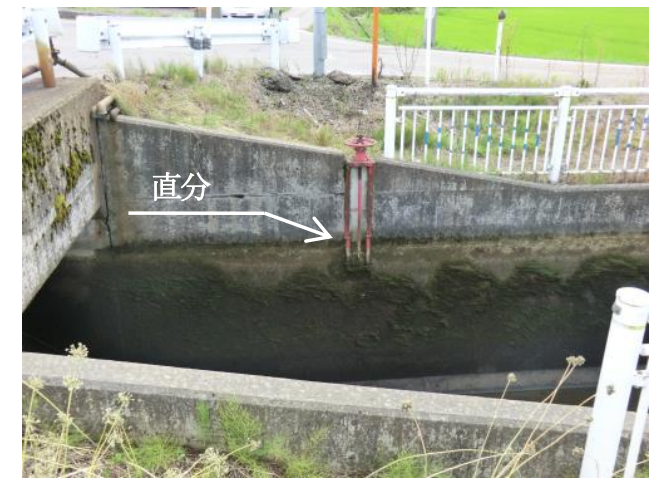

図-5 直分の状況

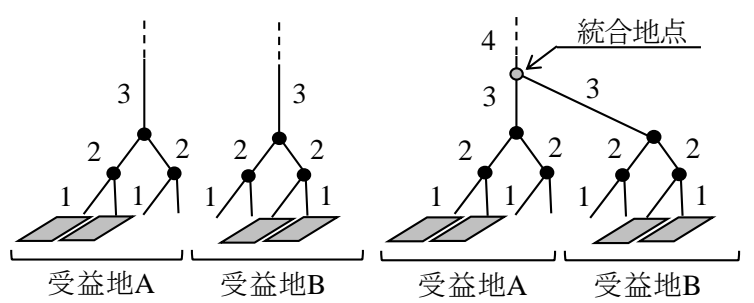

(a) 水路の統合前

（b）水路の統合後

図-6 適切な水路統合時の用水路位数と評価

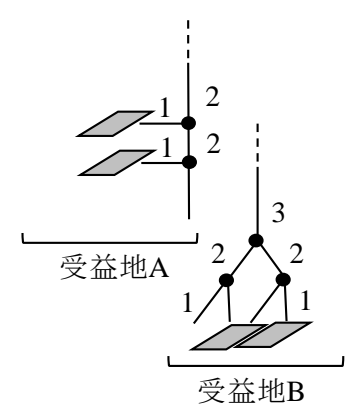

（a）水路の統合前

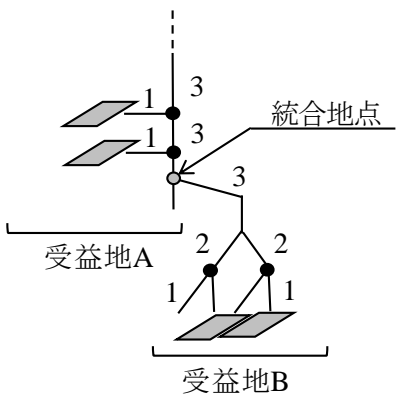

(b) 水路の統合後
図-7 不適切な水路統合時の用水路位数と評価

いる. 図-7 (b) は，受益地Aのネットワークに，より 高次の階層を有寸る受益地Bのネットワークが統合され， 両者の受益地に送水する導水路線を共有化する場合を表 している.ここで共有化区間の用水路位数に着目すると， 統合前は用水路位数 2 であったのに対し, 統合後は用水 路位数 3 となり, 階層が 1 つ上がる. その結果, 受益地 $\mathrm{A}$ で, 用水路位数 3 の水路から用水路位数 1 の水路へ分水す る事態（直分）が発生する. 直分は用水路位数とその ギャップ（2以上）で定義できることも分かる.

\section{（3）直分問題の解決方法}

図-8は，幹線水路からの直分を解消寸るための対策と 用水路位数との関係を表す．なお，図-8（a）および図8 (b) の対策法は, 図-7 (b) の問題に対応している. 図-8（a）は，二連化による対策事例である．受益地A およびBのネットワークの統合により, 共有化された水 路区間を，二連化により再分割する。 その結果，受益地 Aに向から用水路の位数は, 統合前の2（図-7（a））に 戻され，その結果，水路共有区間は専有区間に変更され， 
直分が解消される．図-8（b）は，バイパスによる対策 事例である．二連化と同様の方法で，直分の解消が説明 できる．ネットワークで扱う場合，二連化とバイパス化 の評価は類似のものと考えられ, 以降はこれらを総称し て「複線化」と表記する。

以上のように，用水路ネットワークの階層性と密接な 関わりを持つ直分問題の発生と，その対策の合理性を分 析するためには，階層に基づく用水路位数の考え方が有 効であることが分かる.

\section{4. 番水問題への適用事例}

\section{（1）番水の概要}

番水とは，農家の長年の経験や伝統に基づき，配水順 序，流量，送水・断水時間等のルールによって合意形成 された水利慣行である. 番水の目的は, 水田・畑地灌泊 用水のための水源量が一定以下に制限されたとき，均等 で, 精度よく, 公平に, 対象とする受益地全体に用水を 行き渡らせることである，番水は，幹線・支線・末端水 路と, 様々な管理対象範囲で実施され, 一般的に, 渴水 状況が峳しくなるにつれて，対象範囲が拡大し，管理レ ベルが高くなる.

図-9は，開水路の支線用水路での番水のようすを表し ている. 開水路における分水の制御機構はセキである. 番水ブロックの下流に位置する本線にセキを設け, 所定 の分水位を確保して, 配水を行う。また, 堰上げを行う 構造は, スライドゲート, 転倒ゲート, 角落とし（図一 9）等様々であり，その規模も戋場・支線・幹線水路レ ベルで異なる.

\section{（2）渇水時における長大水路の階層問題と対策}

前章に引き続き長大幹線用水路を検討対象とする，長 大幹線用水路は，もともと上下流の均等な配水を使命と しているが，渴水時においてはより高度な配水技術が求 められる. 図-10は，長大水路の用水路ネットワークに おける平常時 (非渇水時) の典型的な水路階層の構成を 示している. 最も高次の用水路位数を 3 として, 主幹線 が水路階層を維持しながら，支線・末端水路に向けて階 層を下げる. 一方，渇水時において，非渴水時と全く同 じルールが適用されるならば，図中の水路階層3の水路 は, 本線下流に沿って水路階層を維持できないことは明 らかである．維持できない原因は，流量の減少と分水位 の減少であり，下流になるほど不公平が発生する.

このことは, 長大幹線用水路の寸べての分水地点が主 幹線を空間的に共有せざるを得ない以上，避けられない 問題であり, その基本的構造は, 直分問題と同じである. したがって, 複線化はこの問題に対しても有効である.

図-11（a）に，最下流の番水ブロックへ導水するために, 複線化を行った場合の用水路位数の変化を示した.

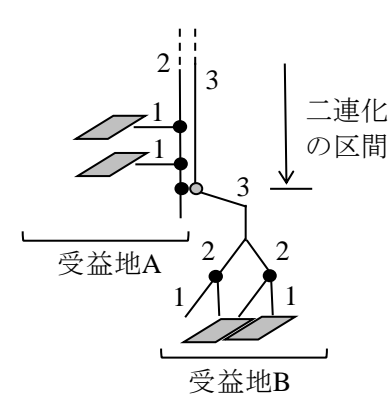

(a) 二連化

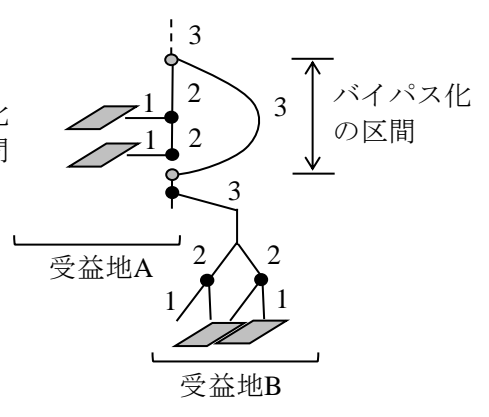

(b) バイパス化
図-8 幹線水路から直分を解消するための対策と用水 路位数の関係

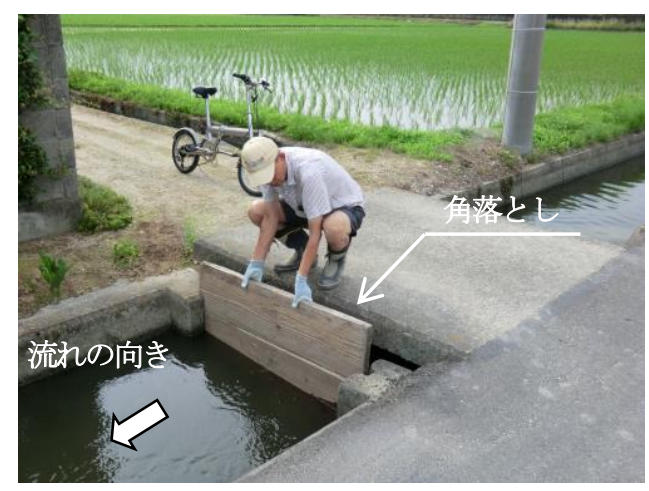

図-9＼cjkstart支線水路レベルの番水状況

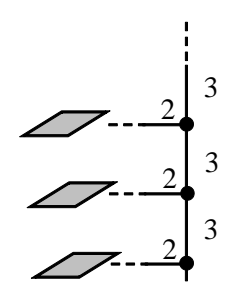

図-10 長大水路の分水における用水路位数

\section{（3）番水による水路階層の表示}

図-11（b）は，最下流から順番に上流へと番水ブロッ クを移行することによる番水のしくみを，用水路位数の 変化によって表示している. 複線化が共有区間の施設改 変によって空間的専有化を進める対策であるのに対し, 番水は，大規模な施設の改変を伴わず，共有幹線区間を 時間的に分割し専有化する手法であると解釈できる.

大規模な施設改変には建設コストがネックになる。一 方，番水の実施に建設コストはかからないものの，用水 の制御操作にかける労力は甚大であり，そのことで，い わゆる「水争い」を通じた悲惨な歴史を背負う地域もあ る. 用水路位数は，いずれの対策に対しても淡々と同様 の評価を与える. 前章での分析とも併せて, 用水路ネッ トワークの持つ機能とそのトレードオフ関係を説明する ためには，この種の指標の導入が有効であることがわか る. 


\section{5. 今後の展望一河川ネットワークとの連携}

\section{（1）排水路ネットワークの構造}

排水路ネットワークの構造もまた，用水路ネットワー クと同様に説明することができる．排水路の場合は，図 -1の回収システムを中心に組み立てられ, 用水路とは逆 向きの階層構造を持つ. そして, 河川のネットワークも また，回収システムを主体とする構造を持っている。こ のことから，排水ネットワークの定式化を通じて，将来 的には，農業水利と治水管理，河川生態系との連結関係 をネットワーク構造で説明することが期待される.

\section{（2）強いインフラを作るための取り組み}

水路と同じような考え方を基に，将来，河川でも同様 のネットワークのモデルが整備され，両者の連携をネッ トワークで評価することが可能になれば，管轄を越えた 新たなインフラ強化の途を模索することが期待される.

\section{（3）あるべき河川の姿との関係}

芦田・江頭・中川卑は，同著書（pp.264）において「河 川環境と治水問題と利水・利用問題は，個別の問題では なく, 流水・流砂という系を通じて調和融合問題として つながる」と述べている，一方，前章までの議論は，す ベて農業水利の説明原理を基にネットワーク定式化のプ ロセスと適用事例を説明しただけである．本研究をここ で留めてしまえば，単に農業水利内部の機能強化のため の評価研究で終わってしまう。今後は，例えば，あるべ き河川の姿を想定して，それに水路がどれだけ貢献でき るのか, などという問題設定を進める必要がある.そし て, 将来どのような問題を設定するにせよ，本稿で提示 したような，異なるシステム間で共有可能なネットワー クの定式化と機能評価手法の整備が不可欠である.

\section{6. 結語}

本研究は, 既存の農業水利システムを対象として, 将 来的なシステムの更新，河川管理との連携をスムーズに 進めることを目的として，ネットワーク化の考え方に基 づく水路機能の新しい評価手法の提案とその有効性の検 証をおこなった. 結論は以下の通り整理される.

（1）水路のもつ3つの基本的な機能-1）分配機能，2）回 収機能，3）連結機能一に基づいて，水路をネットワー ク化するための手法を提案した.

(2) 用水路ネットワークの持つ特徵のひとつである階層 性を客観的に表示するための指標として，用水路位数 (irrigation canal order)を導入した.

（3）農業水利の現場において，用水路ネットワークの直 分問題と, 渇水時の番水システムの問題を事例として,

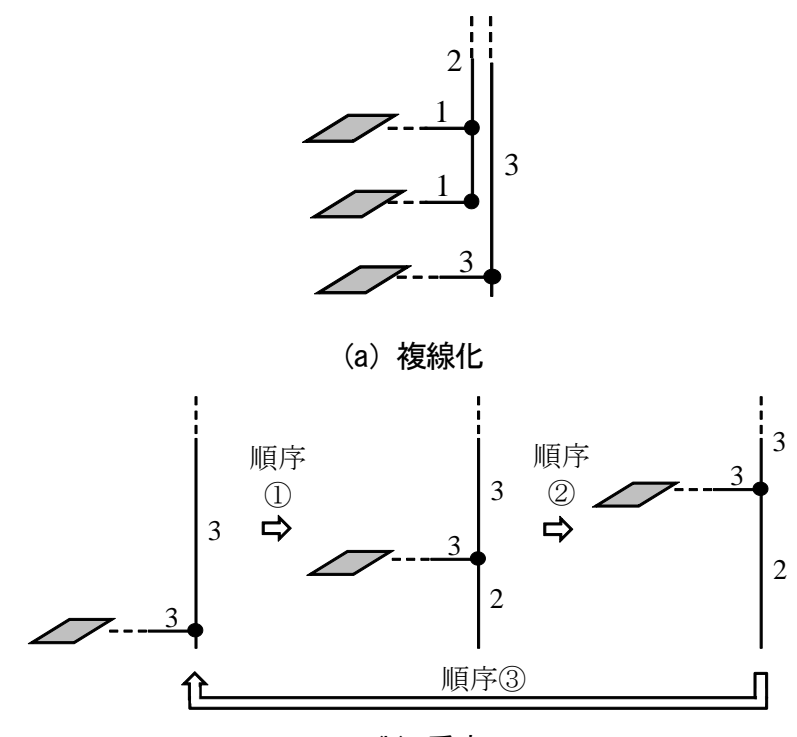

(b) 番水

図-11 複線化と番水における用水路位数

用水路位数を用いた解釈と評価の有効性を説明した.

今後は，農業水利内部の問題に留まらず，河川と水路 が連携できる新たなネットワーク作りを目的として，治 水および他種水利間の複雑な現場問題にも取り組みたい

謝辞 : 本研究をまとめるにあたり，東京海洋大学の渡部 大輔博士からは，ネットワークの分析手法について多く のご示唆を賜りました. ここに記して謝意を表します.

\section{参考文献}

1) 志村博康 : 農業水利と国土, 東京大学出版会, pp.293-296, 1987.

2) 岩田敏靖, 岡本雅美 : 日本の重層的農民水利組織の構造と機 能，農村計画学会論文集，Vol.2，pp.181-185， 2000.

3) 戸川達男 : 血管の分岐の形態とその機能 : 物性研究 36(1), pp.A40-A47, 1981.

4) 佐々木邦博, 米林由美子, 平岡直樹 : 城下町の庭園と庭園を 結ぶ水路の特性, 信州大学農学部紀要, Vol.40 No.1・2, 2004.

5) 河端邦彦，山田圭二郎，中村良男 : 都市空間における遣水型 水路網に関する研究, 土木計画学研究 - 論文集, No.17, 2000.

6) 渡部大輔 : 近接性からみたネットワーク形態解析と輸送シス テム最適化に関する数理的研究, 都市計画 56(4), 110, 2007.

7) Strahler, Arthur, N. : Hypsometric (Area-Altitude) Analysis of Erosional Topography, Bulletin of the Geological Society of America, Vol.63,pp.1117-1142, 1952.

8) U. S. Bureau of Reclamation: Canal Systems Automation Manual, A Water Resources Technical Publication, Vol.1,pp.3,1991.

9) 芦田和男, 江頭進治, 中川一: 21世紀の河川学, 京都大学学 術出版会, pp.261-265, 2008.

（2014. 9. 30受付） 